method of treating vesical hæmorrhage should prove a distinct advance on the methods described by Mr. Swan as being standard ones.

We are, Sir, yours faithfully, C. E. IREDELT.

Guy's Hospital, May 12th, 1914 RALPH ThOMPSON.

\section{MEDICAL PRACTICE UNDER THE INSURANCE ACT: THE ALLE- GATION OF BRIBERY.}

To the Editor of THE LANCET.

SIR,-My attention has been called to the remarks which your Special Commissioner recently made on the subject of the bribing of insurance agents, and I shall be glad if any of your readers who can gire any further information with regard to this matter would communicate with me so that any possible action may be taken to stop a very unfair and odious practice.-I am, Sir, yours faithfully,

\section{R. MI. LEONARD}

Secretary of the Secret Comnussions and Bribery Prevention Let Com Incorporated.

9, Queen-street Place, London, E.C., May 8th, 1914.

THE LATE COLONEL J. O. WILL, R.A.M.C. To the Editor of THE LANCET.

SIR,-I have to thank you for vour great kindness in inserting an appeal from Drs. Blomfield, Dick, and Sichel on my behalf. A rery great many have most kindly responded, and I should be much obliged if you would allow me to conrey to them through your paper my most grateful thanks. am trying to write to them personally but hare not all their addresses. If you will allow me I should like also to publish in rour columns later on a statement of the total amount receired. Again thanking you,

I am, yours truly,

Brunswick Lodge, Dunton Green, May 12th, 1914 K. E. WILL.

\section{WILLIAM HAWES AND ALEXANDER JOHNSON.}

To the Editor of THE LANCET.

SIR,--It is flattering to an occasional writer to find that a medical bistorian so eludite as Dr. Raymond Crawfurd should not only read him, but point out his supposed delinquencies. The gist of Dr. Crawfurd's criticism in your issue of May 2nd is that Hawes was a plagiarist and somewhat of an impostor. But is this quite a fair view of the case? William Hawes is allowed the title of M.D. by his biographer in the "Dictionary of National Biograply," and is also referxed to in the same article as "phvsician to the London Dispensary." This title of M.D. apparently dates from 1780-81, according to his German biographer (Biogr. Lex., 1884).

That he was a plagiarist is open to grave doubt. According to his biographer in the "Dictionary of National Biography" he derived his ideas from his friend Dr. Cogan's translation from the Dutch of "Memoirs of the Society instituted at Amsterdam in favour of Drowned Persons," 1767-71. This translation was made in 1773 on Thomas Cogan's return from Holland. Hawes probably used Cogan's translation again when writing on the subject of premature burial in the Annual Register (1777).

Alexander Johnson's chief pamphlet, published in 1773 , republished under a different title in the sime year, is mainly made up of cases "selected from the
(Dutch) Society's account of the success of its under. taking." These cases fill nearly the whole pamphlet from p. 11 to p. 138 . It is, in fact, little more than a compilation or transcript from the Dutch. The few introductory pages scarcely count, except that with some appearance of spleen they omit the names of Hawes and Cogan from a list of those interested in the recovery of the drowned. Dr. Fothergill's name does appear in the list, and again he figures with Hawes and Cogan in the foundation of the Royal Humane Society. He was apparently in sympathy with both sides and was, moreorer, an M.D. (though Cogan was one, too, for the matter of that in 1774).

Spilsbury may have hated Hawes for some private reason, and Johnson may have looked down on Hawes as upon a mere apothecary in 1773 . Cogan's translation was probably at the root of the quarrel. Time with its love of shocking revelations may perhaps show that Johnson lifted Cogan's work! Cogan was certainly a good Dutch scholar, and so fond of Holland that he lived there in the great house of the Zulesteins for some year's. He certainly worked very hard with Hawes to found the Royal Humane Society. Both surely deserve halos if only for their powers as organisers.-I am, Sir, yours faithfully,

Nay 7th, 1914. ThE WRITER OF THE ANNOTATION.

\section{THE NATIONAL INSURANCE ACT.}

\section{SAYATORIUM BeneftT IN MIDdLesex.}

Is Middlesex the county council has signified its willingness to provide treatment for all persons suffering from tuberculosis, whether insured or uninsured. The Insurance Committee, therefore, has entered into an agreement to hand over to the county council all moneys in the sanatorium fund after payment for domiciliary treatment, drugs, medical extras, and administrative expenses. It is estimated, howerer, that the available balance will by no means suffice to meet the cost to which the county council will be put in respect of tuberculous insured persons, but will, in fact, only maintain 100 out of 250 beds in institu. tions required for insured persons. As a member of the Insurance Committee put it at a recent meeting, of 250 persons who have paid by their insurance contributions for institutional treatment 150 will be in the position of having to receive treatment at the cost of the rates, the insurance fund being inadequate. Not unnaturally, longing eyes were cast upon the domiciliary $6 d$. in the hope of making up the deficit, and a proposal was actually made by a member of the committee to reduce the amount set aside for domiciliary treatment and to increase to that extent the contribution towards the expenses of the county council. However, the suggestion was not persisted in and the agreement with the council was ratified. The length of the agreement was fixed at 60 years in order to make it coterminous with the period for which the council has arranged to raise a loan for capital expenditure. Nevertheless the hope was expressed that long before 60 year's had elapsed tuberculosis would be as un. important as some of the zymotic diseases are now. The county council agrees to place 60 beds in sanatoriums and 40 in hospitals at the disposal of the Insurance Committee. On April 29th 156 